\title{
LEARNING STYLE, INTERCULTURAL SENSITIVITY, AND INTERNATIONAL ATTITUDES: A CASE OF A JAPANESE UNIVERSITY
}

\author{
Michiko Toyama, \& Yoshitaka Yamazaki \\ Department of Business Administration, Bunkyo University (Japan)
}

\begin{abstract}
We explored how learning style relates to intercultural sensitivity and how these two variables are associated with international attitudes in the context of a Japanese university. Since the Japanese Ministry of Education, Culture, Sports, Science and Technology articulated the magnitude of shifting towards globalization of Japanese higher education, many universities have continued to advance initiatives to prepare their students for globalized contexts. Little is known about how learning style relates to psychological variables of cross-cultural communication. Thus, the present empirical study attempted to fill this gap. Participants of the study were 109 Japanese students enrolled at a Japanese university. We applied three measures: Kolb's Learning Style Inventory, Chen and Starosta's Intercultural Sensitivity Scale, and Yashima's International Posture measure. Because factor structure with constituent items of the Intercultural Sensitivity Scale was unresolved, we initially examined how its latent constructs are configured and then identified four underlying components: Affirmative \& Enjoyment Interaction, Negative Perceptions, Anxious Interaction, and Respect of Cultural Differences. The International Posture consists of four themes to measure Intercultural Approach Tendency, Interest in International Vocation, Interest in Foreign Affairs, and Willingness to Communicate to the World. Results of regression analysis illustrated that a learning style variable of more acting over reflecting significantly related to the sensitivity variable of Anxious Interaction $(\beta=-0.26, p<0.01)$. Subsequently, results of regression analysis indicated that a learning style variable of more thinking over feeling was significantly associated with Intercultural Approach Tendency $(\beta=-0.19, p<0.01)$, while that of more acting over reflecting was significantly associated with Intercultural Approach Tendency $(\beta=0.16, p<0.05)$ and Interest in International Vocation $(\beta=0.30, p<0.01)$. As to relationships between intercultural sensitivity and international attitudes, the results showed that Affirmative \& Enjoyment Interaction was significantly associated with all four international attitudes ( $\beta s$ ranged from 0.24 to 0.57 ); Anxious Interaction significantly related to only Willingness to Communicate to the World $(\beta=-0.33, p<0.01)$; and Respect of Cultural Differences was significantly linked with Intercultural Approach Tendency $(\beta=0.20$, $p<0.01)$ and Interest in Foreign Affairs $(\beta=0.28, p<0.01)$. The results suggest that learning style relates to intercultural sensitivity and international attitudes, but the relationship depends on the type of learning style variable and the specific factor in intercultural sensitivity and international attitudes.
\end{abstract}

Keywords: Learning style, intercultural sensitivity, international attitudes, Japanese higher education.

\section{Introduction}

The Japanese government initiated a strategy to advance the globalization of Japanese higher education. This initiative established the goal of receiving 300,000 international students from foreign countries until 2020 and increasing the number of Japanese students who study abroad (MEXT, 2008). To facilitate this initiative, the Japan Student Service Organization with the cooperation of Japanese firms launched a study abroad program for Japanese students in 2014. The program aims to send abroad a total of 180,000 Japanese university and high school students (MEXT, 2020). The implementation of the government strategy has allowed Japanese educational institutions to educate Japanese students not only for development of English proficiency (Toyama \& Yamazaki, 2019a) but also for the capability to deal with cross-cultural and international situations. It is thought that Japanese students need to learn in cross-cultural contexts where they feel, think, and act to acquire demanding competencies and knowledge. In line with this perspective, our study sought to understand a relationship between a way of 
learning, which is called 'learning style,' and psychological aspects of Japanese university students in terms of cross-cultural communication.

The literature on such a relationship in the area of cross-cultural and international studies is limited, involving only a handful of reports on work attitudes in an international context (Yamazaki \& Kayes, 2010) and cultural intelligence of global leaders (Li, Mobley, \& Kelly, 2013). Although intercultural sensitivity and international attitudes have been examined in Japanese academic contexts (see Elwood \& Monoi, 2015; Suzuki \& Saito, 2016; Yashima \& Zenuk-Nishide, 2008), we do not know much about how these two cross-cultural psychological variables are related to learning style.

Intercultural sensitivity may change and develop over time (Straffon, 2003), so several studies have examined the effect of cultural sensitivity training (Wade \& Bernstein, 1991), English as a foreign language education (Bordie, 1970), and healthcare study (Bohanon, 2018). For the present study, therefore, it was assumed that intercultural sensitivity can be learned and developed based on experience. Accordingly, we explored how individuals' learning style relates to intercultural sensitivity followed by a study of the association of those two variables with international attitudes.

\section{Literature review}

\subsection{Learning style}

Learning style is defined as "an individual's preferred way of responding (cognitively and behaviourally) to learning tasks which change depending on the environment or context" (Peterson, Rayner, \& Armstrong, 2009, p. 520). Among multiple learning models proposed in the literature (Cassidy, 2004), we used Kolb's (1984) experiential learning model because it has been applied in numerous cross-cultural studies (Yamazaki, 2005). It is characterized by focus on individuals' experiences as a source of learning (Kolb, 1984; Kolb \& Kolb, 2017). Kolb's learning model consists of four learning modes: concrete experience (CE), reflective observation (RO), abstract conceptualization (AC), and active experimentation (AE). The CE mode requires feeling and sensing in the immediate experience of a learning situation, while the $\mathrm{AC}$ mode, in contrast, calls for thinking and using logic to form concepts based on the experience. The two modes in this dimension involve different ways of grasping experience. The RO learning mode requires reflecting on the experience, while the AE mode involves action to examine the conceptualized idea. The two modes in this dimension serve to transform an individual's experience in a distinct way. Each person tends to have a preference for one learning mode over the other in each learning dimension.

\subsection{Intercultural sensitivity and international attitudes}

Intercultural sensitivity describes "the ability to discriminate and experience relevant cultural differences" (Hammer, Bennet, \& Wiseman, 2003, p. 422). Individuals can acquire and develop this ability in a learning situation. Within the cross-cultural literature, scholars have largely agreed that individuals who are more interculturally sensitive will become more interculturally competent (Wang \& Zhou, 2016). Chen and Starosta (2000) developed the Intercultural Sensitivity Scale with 24 items. The scale was designed to measure individuals' intercultural sensitivity as the affective component of intercultural communication, which is the core construct of an upper layer built on affective, cognitive, and behavioral aspects (Chen \& Starosta, 2000). The Intercultural Sensitivity Scale has a five-factor structure: Interaction Engagement, Respect of Cultural Differences, Interaction Confidence, Interaction Enjoyment, and Interaction Attentiveness. However, several studies documented inconsistent factorial configurations, including a three-factor structure (Suzuki \& Saito, 2016) and a five-factor structure with different constituent items (Petrovic, Starcevic, Chen, \& Komnenic, 2015). In this study, we attempted to examine the configuration of the Intercultural Sensitivity Scale before applying it for analysis.

International attitudes have been investigated in the domain of English as a foreign language as the concept of International Posture proposed by Yashima (2002, 2009). This concept was influenced by Gardner's construct of Integrativeness, developed to identify individuals' attitudes towards cross-cultural or international situations/events. The International Posture measure originally had five subscales corresponding to five factors. For this study, however, we eliminated the subscale of Ethnocentrism due to its low psychometric values, as reported by Yashima (2002). The other four factors of International Posture include Intercultural Approach Tendency, Interest in International Vocation, Interest in Foreign Affairs, and Willingness to Communicate to the World. 


\section{Methods}

Participants for this study were 109 undergraduates of a Japanese university located near Tokyo. The students were majoring in business management or information society. Of the 109 participants, $44(40 \%)$ were women and $65(60 \%)$ were men. Their average age was 20.1 years $(\mathrm{SD}=0.65)$. In the spring 2019 semester, one of the authors distributed survey questionnaires to the students in class.

The questionnaires included Kolb's (1999) Learning Style Inventory, the Intercultural Sensitivity Scale, and the International Posture measure with demographic questions. Before analyzing a relationship between learning style, intercultural sensitivity, and international attitudes, the factor structure of the Intercultural Sensitivity Scale consisting of 24 items was examined, as discussed earlier. We conducted exploratory factor analysis using the same sample, applying the method of maximum likelihood with the direct oblimin. Although five factors were extracted employing a technique of a factor loading of at least 0.5 with the guideline of eigenvalues $>1$, we decided to adopt four factors with a total of 15 items because one factor had only one item that also had cross-loading with another factor. Subsequently, confirmatory factor analysis showed a chi-square score of $210.04(p<0.01)$, goodness of fit of 0.83 , comparative fit index of 0.84 , and root mean square error of approximation of 0.10 . The four factors comprised Affirmative \& Enjoyment Interaction (6 items), Anxious Interaction (3 items), Negative Perceptions ( 3 items), and Respect of Cultural Differences ( 3 items). The Cronbach's $\alpha$ coefficients for those components ranged from 0.70 to 0.84 , all of which were an acceptable level. For the International Posture measure, the Cronbach's $\alpha$ coefficients were 0.78 for Intercultural Approach Tendency ( 7 items), 0.72 for Interest in International Vocation (6 items), 0.58 for Interest in Foreign Affairs (4 items), and 0.66 for Willingness to Communicate to the World (6 items).

\section{Results and discussion}

This study applied regression analysis of how learning style relates to intercultural sensitivity, as well as how learning style and intercultural sensitivity relate to international attitudes. Results of the regression analysis indicated that a learning style variable of more acting over reflecting (AE-RO) significantly related to Anxious Interaction $(p<0.01)$ and was marginally associated with Affirmative and Enjoyment Interaction $(p<0.10)$. However, other relationships between learning style variables and intercultural sensitivity variables were insignificant. This result implies that individuals who learn by using more action than reflection will have less anxiety when interacting with culturally different people and tend to have more Affirmative and Enjoyment Interaction. Table 1 summarizes results of the regression analysis.

The results are consistent with those of prior studies that investigated learning style and state and trait anxiety (Ayalp \& Özdemir, 2016; Toyama \& Yamazaki, 2019b). Compared with those with a Converging learning style (with a focus on $\mathrm{AC}$ and $\mathrm{AE}$ ), those with a Diverging learning style (with a focus on CE and RO) had more state and trait anxiety (Toyama \& Yamazaki, 2019b) and more test anxiety (Ayalp \& Özdemir, 2016). It seems that too much reflection without action elicits pessimistic feelings that lead to anxiety in general. In contrast, those with an action orientation in a learning situation may tend to have optimistic feelings when facing challenges and taking risks, leading to increased opportunities for development in the ability of affirmative and enjoyable interaction.

Table 1. Results of Regression Analysis of Learning Style and Intercultural Sensitivity.

\begin{tabular}{lcccc}
\hline & \multicolumn{4}{c}{ Dependent variables } \\
\cline { 2 - 5 } & $\begin{array}{c}\text { Affirmative \& } \\
\text { Enjoyment Interaction }\end{array}$ & Anxious Interaction & Negative Perceptions & $\begin{array}{c}\text { Respect of Cultural } \\
\text { Differences }\end{array}$ \\
\cline { 2 - 5 } Variable entered & 0.03 & \multicolumn{2}{c}{$\beta$} & -0.02 \\
\hline $\begin{array}{l}\text { AC-CE } \\
\text { (thinking vs. feeling) }\end{array}$ & $0.19^{\dagger}$ & -0.13 & -0.01 & 0.03 \\
$\begin{array}{l}\text { AE-RO } \\
\text { (acting vs. reflecting) }\end{array}$ & 1.84 & $-0.26^{* *}$ & -0.15 & 0.09 \\
\hline$F$ & 0.03 & $4.04^{*}$ & 1.25 & 0.00 \\
\hline$R^{2}$ & 0.07 & 0.02 & \\
\hline
\end{tabular}

Note. $N=109 ; * * p<0.01, * p<0.05,{ }^{\dagger} p<0.10$. 
Table 2. Results of Regression Analysis of Learning Style, Intercultural Sensitivity, and International Attitudes.

\begin{tabular}{|c|c|c|c|c|}
\hline \multirow[b]{3}{*}{ Variable entered } & \multicolumn{4}{|c|}{ Dependent variables } \\
\hline & $\begin{array}{c}\text { Intercultural } \\
\text { Approach Tendency }\end{array}$ & $\begin{array}{c}\text { Interest in } \\
\text { International Vocation }\end{array}$ & $\begin{array}{c}\text { Interest in Foreign } \\
\text { Affairs }\end{array}$ & $\begin{array}{l}\text { Willingness to } \\
\text { Communicate to the World }\end{array}$ \\
\hline & \multicolumn{4}{|c|}{$\beta$} \\
\hline $\begin{array}{l}\text { AC-CE } \\
\text { (thinking vs. feeling) }\end{array}$ & $-0.19 * *$ & -0.12 & 0.00 & $-0.14^{\dagger}$ \\
\hline $\begin{array}{l}\text { AE-RO } \\
\text { (acting vs. reflecting) }\end{array}$ & $0.16^{*}$ & $0.30 * *$ & $-0.16^{\dagger}$ & 0.02 \\
\hline $\begin{array}{l}\text { Affirmative \& } \\
\text { Enjoyment Interaction }\end{array}$ & $0.57 * *$ & $0.24 *$ & $0.27 * *$ & $0.45^{* *}$ \\
\hline Anxious Interaction & -0.02 & -0.15 & -0.08 & $-0.33 * *$ \\
\hline Negative Perceptions & -0.02 & -0.03 & 0.03 & 0.01 \\
\hline $\begin{array}{l}\text { Respect of Cultural } \\
\text { Differences }\end{array}$ & $0.20^{* *}$ & 0.07 & $0.28 * *$ & $0.15^{\dagger}$ \\
\hline$F$ & $23.73 * *$ & $6.43^{* *}$ & $4.76^{* *}$ & $12.37 * *$ \\
\hline$R^{2}$ & 0.58 & 0.27 & 0.22 & 0.42 \\
\hline
\end{tabular}

Note. $N=109 ; * * p<0.01,{ }^{*} p<0.05,{ }^{\dagger} p<0.10$.

Table 2 illustrates results of regression analysis for how two learning style variables and four intercultural sensitivity variables relate to four international attitudes. The results showed that the learning style variable of more thinking over feeling (AC-CE) was significantly negatively associated with Intercultural Approach Tendency $(p<0.01)$ and marginally negatively related to Willingness to Communicate to the World $(p<0.10)$. Since the learning mode of concrete experience (feeling) is linked with a competency of forming good human relationships with others (Boyatzis \& Kolb, 1991), those who use the feeling learning mode more than the thinking learning mode tend to be more communicative and more involved with foreigners. The results also indicated that a learning variable of more acting over reflecting (AE-RO) was significantly associated with Intercultural Approach Tendency $(p<0.05)$ and Interest in International Vocation $(p<0.01)$ and was marginally related to Interest in Foreign Affairs $(p<0.10)$. An active orientation toward learning might lead to development of more interests relevant to the outer world, in contrast to a reflective orientation of learning that engages the inner world.

As to the relationship between intercultural sensitivity and international attitudes, results of the regression analysis indicated that Affirmative \& Enjoyment Interaction was significantly associated with the four international attitudes; Anxious Interaction significantly negatively related to only Willingness to Communicate to the World ( $p<0.01$ ); and Respect of Cultural Differences was significantly linked with Intercultural Approach Tendency $(p<0.01)$ and Interest in Foreign Affairs $(p<0.01)$ and was marginally related to Willingness to Communicate to the World $(p<0.10)$. It is logical that intercultural sensitivity variables have a strong relationship with international attitudes.

\section{Conclusions}

Our study explored how learning style, intercultural sensitivity, and international attitudes are associated with each other. The results led us to conclude that learning style relates to intercultural sensitivity and international attitudes, but the relationship depends on the type of learning style variables and the type of underlying factors in intercultural sensitivity and international attitudes. More specifically, a learning variable of active over reflective modes may be more influential than that of thinking over feeling modes in terms of sensitivity and attitudes in a cross-cultural context. Also, it would be reasonable to say that the two sensitivity factors of Affirmative \& Enjoyment Interaction and Respect of Cultural Differences play an important role in changes of international attitudes.

\section{References}

Ayalp, G. G., \& Özdemir, N. (2016). Relationship between test anxiety and learning styles of architecture undergraduates. Creative Education, 7(2), 364-375. doi:10.4236/ce.2016.72036

Bohanon, M. (2018). Expanding cultural sensitivity training beyond the curriculum. Insight into Diversity, $90(4-5), 60-62$. 
Bordie, J. (1970). Cultural sensitivity training for the Teacher of Spanish-speaking children. TESOL Quarterly, 4(4), 337-342. doi:10.2307/3585764

Boyatzis, R. E., \& Kolb, D. A. (1991). Assessing individuality in learning: The Learning Skills Profile. Educational Psychology, 11(3-4), 279-295. doi:10.1080/0144341910110305

Cassidy, S. (2004). Learning styles: An overview of theories, models, and measures. Educational Psychology, 24(4), 419-444. doi:10.1080/0144341042000228834

Chen, G., \& Starosta, W. J. (2000). The development and validation of the Intercultural Sensitivity Scale. Human Communication, 3(1), 3-14.

Elwood, J. A., \& Monoi, N. (2015). Measuring carefully: Validating the International Posture-Child instrument. JALT Journal, 37(2), 119-146.

Hammer, M. R., Bennett, M. J., \& Wiseman, R. (2003). Measuring intercultural sensitivity: The intercultural development inventory. International Journal of Intercultural Relations, 27(4), 421-443. doi:10.1016/S0147-1767(03)00032-4

Kolb, A. Y., \& Kolb, D. A. (2017). The experiential educator: Principles and practices of experiential learning. Kaunakakai, HI: EBLS Press.

Kolb, D. A. (1984). Experiential learning: Experience as a source of learning and development. Englewood Cliffs, NJ: Prentice-Hall.

Kolb, D. A. (1999). Learning Style Inventory, Version 3. Boston, MA: TRG Hay/McBer.

Li, M., Mobley, W. H., \& Kelly, A. (2013). When do global leaders learn best to develop cultural intelligence? An investigation of the moderating role of experiential learning style. Academy of Management Learning \& Education, 12(1), 32-50. doi:10.5465/amle.2011.0014

MEXT. (2008). The outline of the plan for 300,000 international students (留学生 30 万人計画の骨子と りまとめの考え方). Retrieved January 4, 2020, from https://www.mext.go.jp/b_menu/ shingi/chukyo/chukyo4/houkoku/attach/1249711.htm

MEXT. (2020). Tobitate! Study abroad JAPAN (トビタテ!留学 JAPAN). Retrieved January 4, 2020, from https://tobitate.mext.go.jp/about

Peterson, E., Rayner, S. G., \& Armstrong, S. J. (2009). Researching the psychology of cognitive style and learning style: Is there really a future? Learning and Individual Differences, 19(4), 518-523. doi:10.1016/j.lindif.2009.06.003

Petrovic, D. S., Starcevic, J., Chen, C., \& Komnenic, D. (2015). Intercultural Sensitivity Scale: Proposal for a modified Serbian version. Psihologija (Beograd), 48(3), 199-212. doi:10.2298/PSI1503199P

Straffon, D. A. (2003). Assessing the intercultural sensitivity of high school students attending an international school. International Journal of Intercultural Relations, 27(4), 487-501. doi:10.1016/ S0147-1767(03)00035-X

Suzuki, Y., \& Saito, S. (2016). Development of Intercultural Sensitivity Scale in Japanese. Bulletin of Graduate School of Human Development and Environment, Kobe University, 9(2), 39-44.

Toyama, M., \& Yamazaki, T. (2019b). How learning style relates to state and trait anxiety among Japanese freshmen transitioning to university. In C. Pracana \& M. Wang (Eds.), Psychology applications and developments $V$ (pp. 3-13). Lisbon, Portugal: In Science Press.

Toyama, M., \& Yamazaki, Y. (2019a). English proficiency requirements for international students as an admissions factor for overseas universities. Journal of Public and Private Management, 5(1), 1-10.

Wade, P., \& Bernstein, B. L. (1991). Cultural sensitivity training and counselor's race effects on black female clients' perceptions and attrition. Journal of Counseling Psychology, 38(1), 9-15. doi:10.1037/0022-0167.38.1.9

Wang, W., \& Zhou, M. (2016). Validation of the short form of the Intercultural Sensitivity Scale (ISS-15). International Journal of Intercultural Relations, 55, 1-7. doi:10.1016/j.ijintrel.2016.08.002

Yamazaki, Y. (2005). Learning styles and typologies of cultural differences: A theoretical and empirical comparison. International Journal of Intercultural Relations, 29(5), 521-548. doi:10.1016/j.ijintrel. 2005.07.006

Yamazaki, Y., \& Kayes, D. C. (2010). Learning and work satisfaction in Asia: A comparative study of Japanese, Chinese, and Malaysian managers. International Journal of Human Resource Management, 21(12), 2271-2289. doi:10.1080/09585192.2010.509628

Yashima, T. (2002). Willingness to communicate in a second language: The Japanese EFL context. Modern Language Journal, 86(1), 54-66. doi:10.1111/1540-4781.00136

Yashima, T. (2009). International posture and the ideal L2 self in the Japanese EFL context. In Z. Dörnyei \& E. Ushioda (Eds.), Motivation, language identity and the L2 self (pp. 144-163). Clevedon, UK: Multilingual Matters. doi:10.21832/9781847691293-008

Yashima, T., \& Zenuk-Nishide, L. (2008). The impact of learning contexts on proficiency, attitudes, and L2 communication: Creating an imagined international community. System, 36(4), 566-585. doi:10.1016/j.system.2008.03.006 